\title{
VALIDATION OF LICUALA PITTA (ARECACEAE; CORYPHOIDEAE) FROM SOUTHEAST THAILAND
}

\author{
ANDERS S. BARFOD ${ }^{1} \&$ RATCHADA PONGSATTAYAPIPAT ${ }^{2}$
}

\section{SUMMARY}

A new species of Licuala from SE Thailand illegitimately published in 2005 is here validated.

Key words: Arecaceae, Coryphoideae, Licuala, palms, Thailand.

\section{INTRODUCTION}

A new species of Licuala from Chantaburi Province in SE Thailand was recently published by horticulturalist Poonsak Vatcharakorn under the name of Licuala pitta (Vatcharakorn 2005). The name is illegitimate under the International Code of Botanical Nomenclature since no type specimen is cited and no Latin diagnosis is provided. The new species grows sympatrically with $L$. poonsakii Hodel from which it clearly differs by having divided partial inflorescences and much smaller flowers. The combination of character states in L. pitta does not match any other Licuala species.

\section{MATERIALS AND METHODS}

Herbarium specimens from the following herbaria were available to us for comparison: AAU, BKF, C, K, L, P and QBG. All measurements were derived from dried voucher specimens. The flowers were boiled previous to longitudinal sectioning. Indication of colour is based on field observations and label information.

\section{DESCRIPTION OF SPECIES}

Licuala pitta Vatch. ex Barfod \& Pongsattayapipat, spec. nov. - Fig. 1

Palma mediocris, caespitosa, foliis multi-segmentatis, segmentis basin infundibulariter convergentibus, inflorescentia erecta, ad ordinem secundam ramosa, et floribus mediocribus, ovalibus. Licuala spinosa affinis, a qua differt inflorescentia interfolia, pauciramosa, rhachillis florentibus paucioribus et brevioribus, floribus duplo longioribus. - Typus: Barfod, Pongsattayapipat \& Anker 727 (holo AAU; iso BKF, QBG), Thailand, Province of Chantaburi, Makham, Hills by Khiri Than Reservoir, 339 m alt., 13 March 2006.

Licuala pitta Vatch. (2005), nom. nud.

1) Department of Biological Sciences, University of Aarhus, Ny Munkegade, bygn. 1540, DK-8000 Aarhus C, Denmark.

2) Queen Sirikit Botanic Garden, P.O. Box 7 Mae Rim, Chiang Mai 50180, Thailand. 


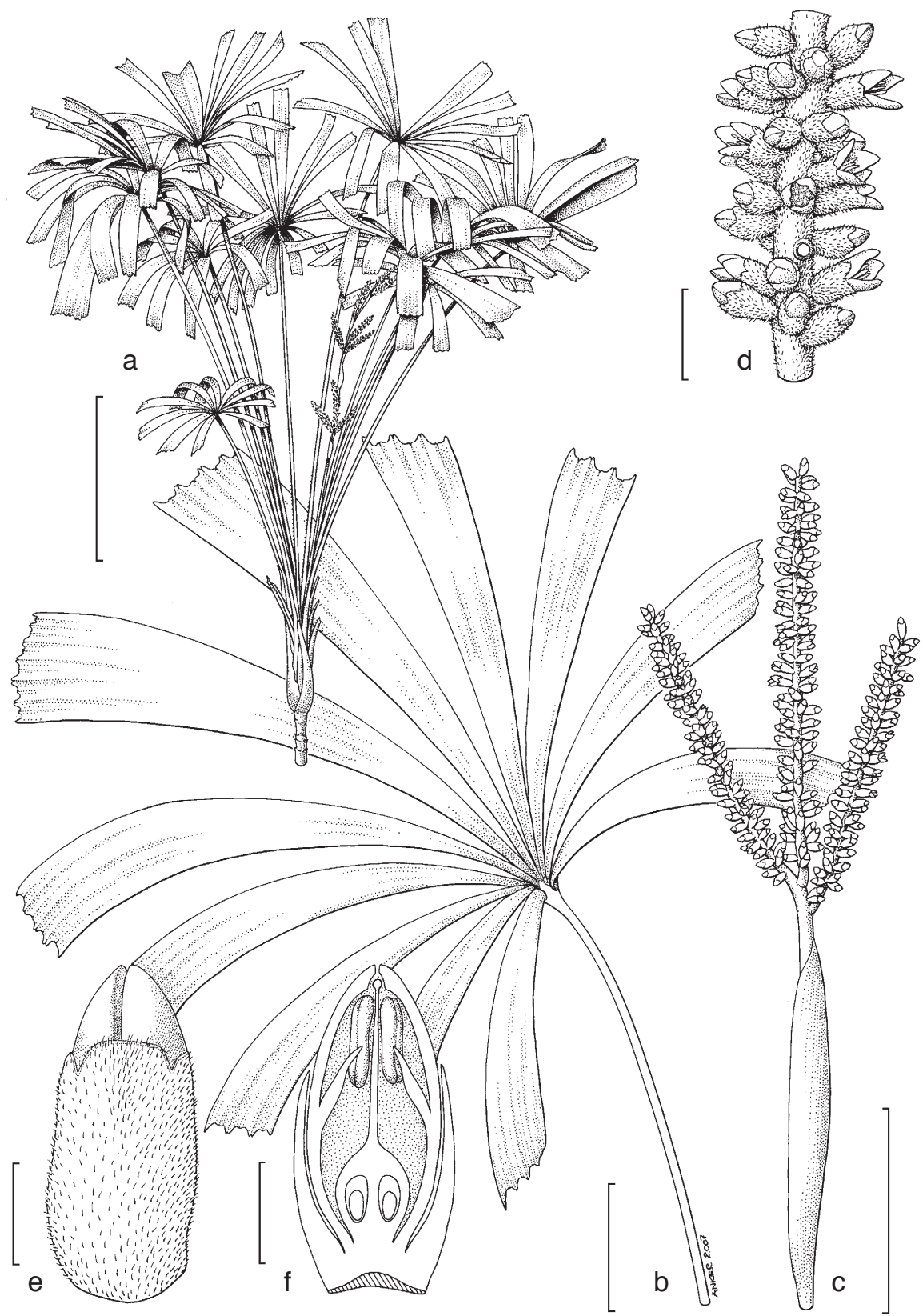

Fig. 1. Licuala pitta Vatch. ex Barfod \& Pongsattayapipat. a. Habit; b. leaf; c. basal-most partial inflorescence; d. detail of rachilla; e. flower in lateral view; f. longitudinal section of flower. - Scale bars: $\mathrm{a}=50 \mathrm{~cm} ; \mathrm{b}=10 \mathrm{~cm} ; \mathrm{c}=5 \mathrm{~cm} ; \mathrm{d}=1 \mathrm{~cm} ; \mathrm{e}, \mathrm{f}=2 \mathrm{~mm}$ (from Barfod, Pongsattayapipat \& Anker 727, AAU). - Drawing by Katja Anker. 
Caespitose palm, 4-8 stemmed, individual stems up to $2.5 \mathrm{~m}$ tall, $2.8-3 \mathrm{~cm}$ diam. below the crown and with $0.5-1 \mathrm{~cm}$ long internodes. Leaves $10-12$ in crown, sheath margins disintegrating into fibrous mesh, eventually dropping off; petiole 120-150 $\mathrm{cm}$ long, 8-10 $\mathrm{mm}$ wide at the base to 4-6 $\mathrm{mm}$ across towards the apex, adaxially flattened to channelled towards the base, abaxially rounded to ridged, armed on lower $30-50 \mathrm{~cm}$, with more or less evenly distributed, irregularly sized, up to $3 \mathrm{~mm}$ long, straight spines; leaf blade $60-70 \mathrm{~cm}$ across, divided in 11-15 segments, with slightly curved to straight lateral margins, converging basally in funnel-like manner, apical segment sessile, undivided, 35-45 cm long, with 9-11 adaxial ribs, midsegments of more or less equal length, with 3 or 4 adaxial ribs, somewhat obliquely truncate, basal segments $30-35 \mathrm{~cm}$ long, with 2-4 adaxial ribs, obliquely truncate; indentations leading to adaxial ribs 5-10 mm long, U-shaped, those leading to abaxial splits 2-5 $\mathrm{mm}$ long, V-shaped. Inflorescences 1 or 2 per ramet, $80-90 \mathrm{~cm}$ long, carrying 4 or 5 partial inflorescences; peduncle as measured to insertion of basal rachis bract $60 \mathrm{~cm}$ long; prophyll $30 \mathrm{~cm}$ long; basal rachis bract bicarinate tubular, $23-27 \mathrm{~cm}$ by $12-15$ $\mathrm{mm}$, covered with patches of ferruginous ramenta particularly basally and towards the margins, loosely fitting, irregularly splitting, 5-12 $\mathrm{mm}$ long; remaining rachis bracts gradually shorter towards the apex with a single, up to $7 \mathrm{~cm}$ long split; basal partial inflorescence inserted $25-30 \mathrm{~cm}$ above its subtending rachis bract, branching near point of insertion, with $1-3,8-12 \mathrm{~cm}$ by $2-3 \mathrm{~mm}$ rachillae, each bearing $70-90$ flowers. Flowers hermaphroditic, protandrous, solitary, bullet-shaped, somewhat triquetrous, 7-7.5 mm long; flowers borne in pairs almost throughout the rachilla, each pair subtended by an inconspicuous up to $0.5 \mathrm{~mm}$ long bract, pedicel very short, calyx $4.8-5$ $\mathrm{mm}$ long, unevenly tomentose, with three shallow, rounded to truncate lobes; corolla $5-5.5 \mathrm{~mm}$ long, splitting to c. $2 \mathrm{~mm}$; androecium fused to corolla for $2.2-2.3 \mathrm{~mm}$, staminal ring c. $1 \mathrm{~mm}$ high; free part of filaments c. $0.5 \mathrm{~mm}$ long; anthers $0.9-1.1 \mathrm{~mm}$ long; ovary 1.5-2 mm long, rounded to attenuate apically; style 3-3.5 mm long; locules situated near the middle of the ovary, $0.5-0.6 \mathrm{~mm}$ long. Fruits unknown.

Etymology - Named after Mr. Pitta Bunnak, who has contributed extensively to palm horticulture in Thailand.

Distribution - Known only from the type locality in Thailand but should be sought for in adjacent Cambodia.

Habitat - This palm is distributed in hill dipterocarp forest and lowland rain forest ranging up to $450 \mathrm{~m}$ asl.

Conservation status - As long as this species has only been recorded in a restricted area it is of possible concern due to urban development and habitat destruction in one of Thailand's fastest developing provinces.

Vernacular names \& Uses - None recorded.

Note - Licuala pitta is similar to the widespread L. spinosa in its caespitose habit and its overall leaf morphology. It differs from that species, however, by the inflorescences being presented among the leaves, the leaf segments converging basally in a funnel-like manner, the fewer and shorter flowering rachillae and the flowers being almost twice as long. Licuala pitta is reminiscent of L. taynguyensis Barfod \& Borchs. (Barfod \& Borchsenius 2000) from Vietnam but that species is solitary, and has much larger inflorescences, with zigzag rachillae that bear fewer, rather large and densely long-haired flowers. 


\section{ACKNOWLEDGEMENTS}

We are grateful to Mr. Poonsak Vatcharakorn for pointing us in the right direction and sharing information with us. Dr. Piyakaset Suksathan provided useful comments to the manuscript. This study was supported by the Carlsberg foundation (grant no. 04-0427/10 to Anders S. Barfod) and the Queen Sirikit Botanic Garden.

\section{REFERENCES}

Barfod, A.S. \& F. Borchsenius. 2000. A new species of Licuala (Arecaceae; Coryphoideae) from the Central Highlands of Vietnam. Brittonia 52: 354-357.

Vatcharakorn, P. 2005. Palms and cycads of Thailand: 126-127. Amarin Printing \& Publishing Public Co. Ltd. 